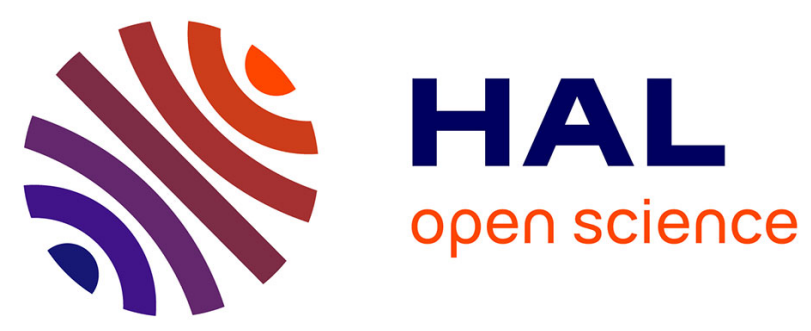

\title{
Multimapping Design of Complex Sensor Data in Environmental Observatories
}

\author{
Hicham Hajj-Hassan, Nicolas Olivier Arnaud, Arnaud Castelltort, Laurent \\ Drapeau, Anne Laurent, Olivier Lobry, Carla Khater
}

\section{To cite this version:}

Hicham Hajj-Hassan, Nicolas Olivier Arnaud, Arnaud Castelltort, Laurent Drapeau, Anne Laurent, et al.. Multimapping Design of Complex Sensor Data in Environmental Observatories. WIMS: Web Intelligence, Mining and Semantics, Jun 2016, Nimes, France. 10.1145/2912845.2912856 . lirmm01381082

\section{HAL Id: lirmm-01381082 https://hal-lirmm.ccsd.cnrs.fr/lirmm-01381082}

Submitted on 14 Oct 2016

HAL is a multi-disciplinary open access archive for the deposit and dissemination of scientific research documents, whether they are published or not. The documents may come from teaching and research institutions in France or abroad, or from public or private research centers.
L'archive ouverte pluridisciplinaire $\mathbf{H A L}$, est destinée au dépôt et à la diffusion de documents scientifiques de niveau recherche, publiés ou non, émanant des établissements d'enseignement et de recherche français ou étrangers, des laboratoires publics ou privés. 


\section{ICNPS}

National Council for Scientific Research

Institut de recherche pour le développement

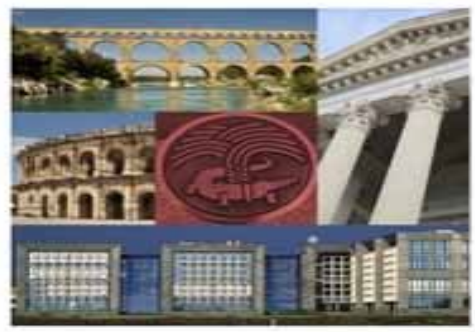

Multimapping Design of Complex Sensor Data in Environmental Observatories

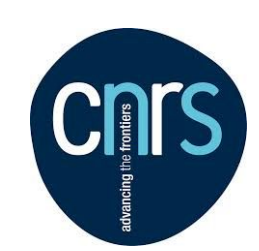

H.Hajj-Hassan, N.Arnaud, A.Castelltort,

L.Drapeau, $\underline{\text { A.Laurent }}$,

O.Lobry, C.Khater

LIFE

Observatoire

Libano-Français de l'Environnement $6^{\text {th }}$ international conference on

Web-Intelligenee, Mining and Semanties 


\section{Environmental resources}

- $\quad$ air quality, water quantity, birds,...

- need for data to understand fundamental questions such as global change

- collecting data: sensors + human as a sensor (HaaS)

- need for data sharing, data publishing

- data models and formats have emerged

- need for data crossing
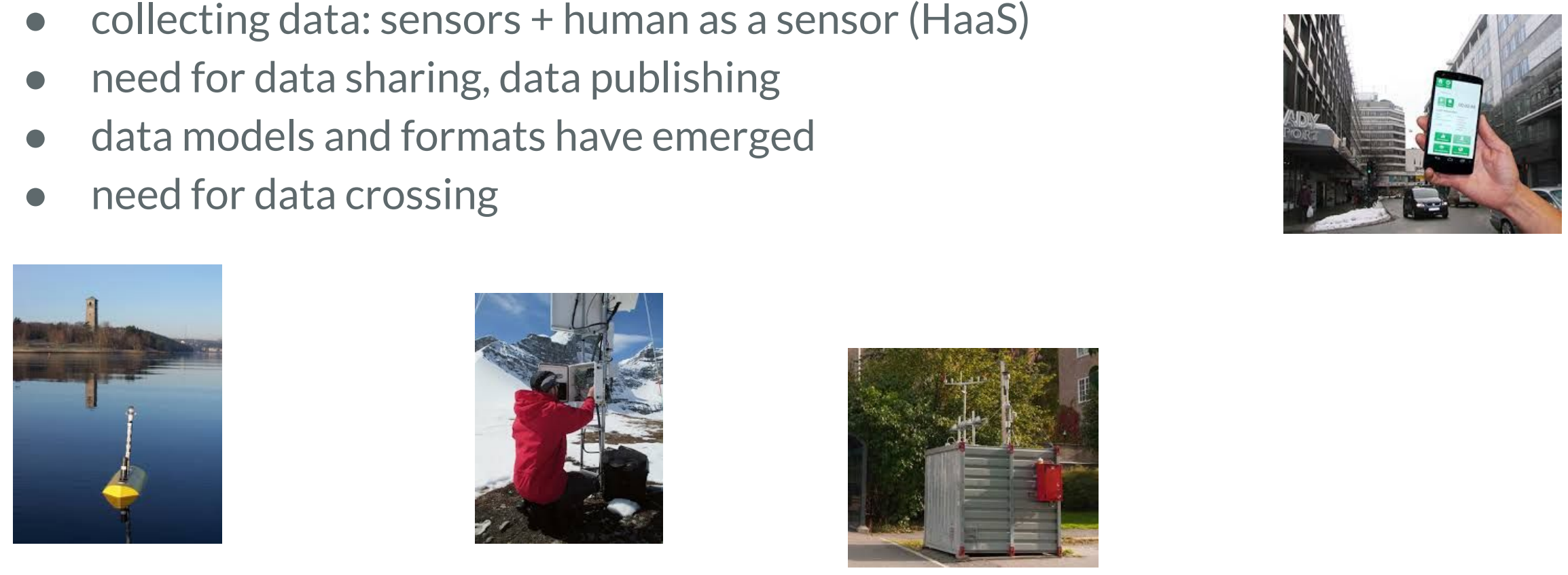


\section{O-Life}

- The Mediterranean basin is a priority area and a leading area for the analysis of environmental data

- shared observatory between France and Lebanon

- with the aim of collecting, perpetuating, sharing, and valorizing environmental information

- creation of an ambitious Circum-Mediterranean observatory network

Objectives of $\mathrm{O}$-Life

- Conduct simultaneously: Observation, Research, Training and Valorization

- Federate skills through common tools and objects

- Organize, share, sustain and enhance environmental data

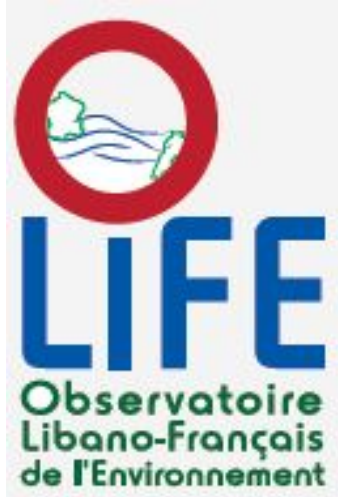




\section{Priorities}

- Build environmental databases of the critical zone in consideration

- Conduct monitoring services: Provide instruments, equipment, assist in the operation and monitoring of sites

- Enhance environmental data and research among scientists, public policy makers, and the public in general, to promote a coordinated approach to sustainable development

- Facilitate the prospective approach and exchange through innovative web services

- Be a force of exploration and proposal for relevant calls for projects 


\section{Building environmental databases}

- crossing heteregeneous data

$\circ$ formats

○ context

- collected for a primary goals and not for publication 


\section{Sensor Data}

- Observations and Measurements (O\&M) framework

\section{2 north}

exploring horizons

- SOS: Sensor Observation Service

- proposed by the OGC (Open Geospatial Consortium) within the Sensor Web Enablement (SWE)

- Several frameworks, our choice: $52^{\circ}$ North 


\section{Concepts}

- Feature of interest

- Phenomenon time.

- Result time

- Procedure

- Observed property

- Result

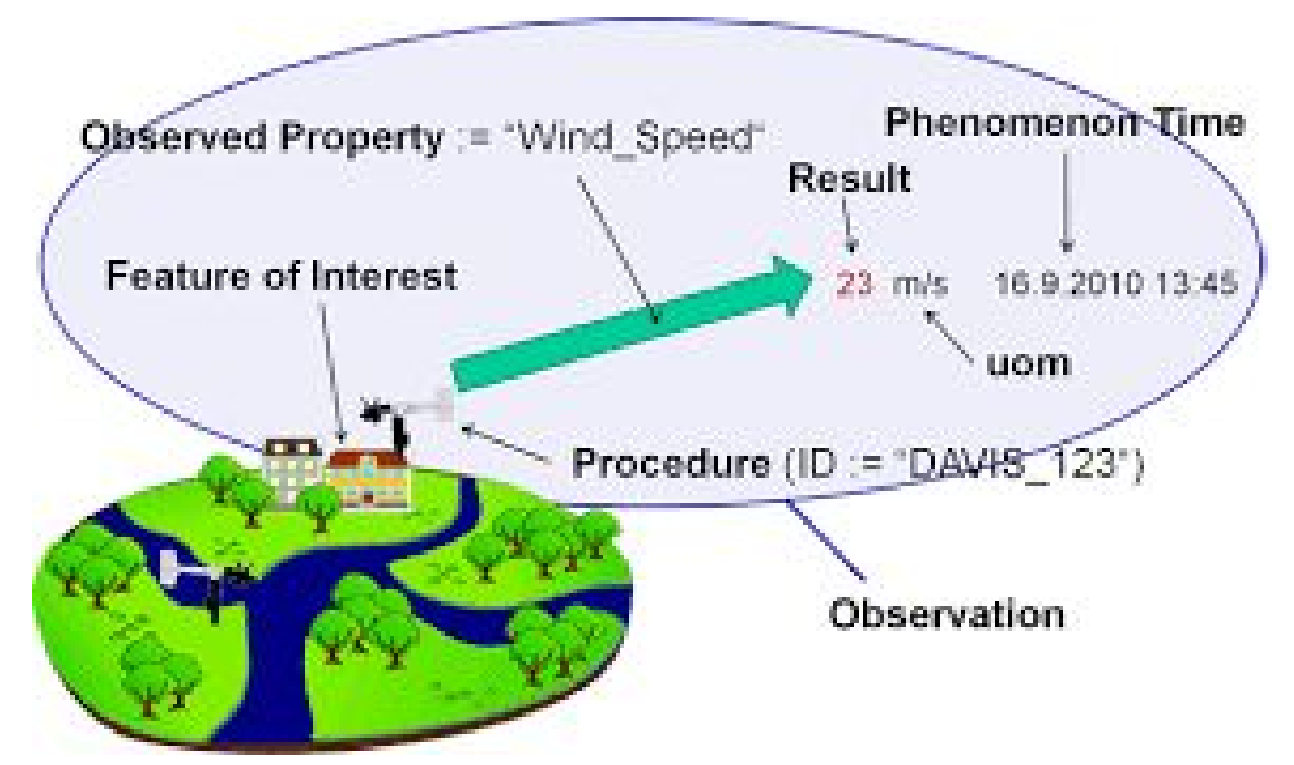

- Unit of Measure 







\section{The need for crossing points of view}

- one observation model is meant as to correspond to one feature of interest - however, it may be the case that several points of view can be considered

- Example

○ following species

\begin{tabular}{|c|c|c|c|c|c|c|c|c|}
\hline Species & Observators & $\begin{array}{c}\text { Date of } \\
\text { observation } \\
\text { (dd/mm/yyy) }\end{array}$ & $\begin{array}{c}\text { Common name } \\
\text { English }\end{array}$ & Village & $\begin{array}{c}\text { Phenology at time of } \\
\text { observation }\end{array}$ & $\mathrm{Nb}$ _of_individuals & Sex & Description \\
\hline Dama & A.A. & $1 / 1 / 2015$ & Fallow deer & Faraya & Adulte & 4 & $M \& F$ & Gray \\
\hline Panthera pardus tulliana & C.K. & $4 / 3 / 2015$ & Anatolian leopard & Ehden & Young & 1 & $\mathrm{~F}$ & Hairy \\
\hline Dama & S.C. & $5 / 12 / 2015$ & Fallow deer & Bsharre & Young & 3 & $\mathrm{M}$ & Long Tail \\
\hline
\end{tabular}




\section{Multi-mappings}

- with the goal to consider alternative features of interest

- some parts of the SSN ontology are refined in order to be able

$\circ$ to represent multiple mappings and

- to point out the existence of multimapping to the users 


\section{Example: Mapping 1}

\begin{tabular}{|c|c|c|c|c|c|c|c|c|}
\hline A & B & C & D & $\mathrm{E}$ & $\mathrm{F}$ & G & H & 1 \\
\hline Species & Observators & $\begin{array}{c}\text { Date of } \\
\text { observation } \\
\text { (dd/mm/yyyy) }\end{array}$ & $\begin{array}{c}\text { Common name } \\
\text { English }\end{array}$ & Village & $\begin{array}{c}\text { Phenology at time of } \\
\text { observation }\end{array}$ & $\mathrm{Nb}$ of_individuals & Sex & Description \\
\hline Dama & A.A. & $1 / 1 / 2015$ & Fallow deer & Faraya & Adulte & 4 & $M \& F$ & Gray \\
\hline Panthera pardus tulliana & C.K. & $4 / 3 / 2015$ & $\begin{array}{c}\text { Anatolian } \\
\text { leopard }\end{array}$ & Ehden & Young & 1 & $\mathrm{~F}$ & Hairy \\
\hline Dama & S.C. & $5 / 12 / 2015$ & Fallow deer & Bsharre & Young & 3 & $\mathrm{M}$ & Long Tail \\
\hline \multicolumn{9}{|c|}{ Mapping_1 } \\
\hline ObservedProperty & Procedure & samplingTime & $\begin{array}{c}\text { phenomenon_de } \\
\text { scription }\end{array}$ & featureOfinterest & propertyValueProvider & propertyValueProvider & propertyValueProvider & propertyValueProvider \\
\hline
\end{tabular}




\section{Example: Mapping 2}

\begin{tabular}{|c|c|c|c|c|c|c|c|c|}
\hline Species & Observators & $\begin{array}{c}\text { Date of } \\
\text { observation } \\
\text { (dd/mm/yyy) }\end{array}$ & $\begin{array}{c}\text { Common name } \\
\text { English }\end{array}$ & Village & $\begin{array}{c}\text { Phenology at time of } \\
\text { observation }\end{array}$ & $\mathrm{Nb}$ of_individuals & Sex & Description \\
\hline Dama & A.A. & $1 / 1 / 2015$ & Fallow deer & Faraya & Adulte & 4 & $M \& F$ & Gray \\
\hline Panthera pardus tulliana & C.K. & 4/3/2015 & $\begin{array}{c}\text { Anatolian } \\
\text { leopard }\end{array}$ & Ehden & Young & 1 & $\mathrm{~F}$ & Hairy \\
\hline Dama & S.C. & $5 / 12 / 2015$ & Fallow deer & Bsharre & Young & 3 & $M$ & Long Tail \\
\hline \multicolumn{9}{|c|}{ Mapping_2 } \\
\hline featureOfinterest & Procedure & samplingTime & $\begin{array}{c}\text { phenomenon_de } \\
\text { scription }\end{array}$ & propertyValueProvider & propertyValueProvider & ObservedProperty & propertyValueProvider & propertyValueProvider \\
\hline
\end{tabular}




\section{Representing multiple mappings}

- introduction of ssn:alternative

- alternative observation

- alternative feature of interest

- alternative observed property 


\begin{tabular}{|l|l|}
\hline \multicolumn{1}{|c|}{ Description } & \multicolumn{1}{c|}{ Proposed Property } \\
\hline Alternative Observation & mssn:AltObservationDesign \\
\hline Alternative Feature of Interest & mssn:altFeatureOfInterest \\
\hline Alternative Observed Property & mssn:altObservedProperty \\
\hline Alternative Observed By & mssn:altObservedBy \\
& \\
\hline
\end{tabular}

- introduction of RDF triplets like:

fauna:species mssn:altFeatureOfInterest ssn:FeatureOfInterest 


\section{Conclusion and Perspectives}

- importance of data crossing in the context of environemental data and climate change

- extension of the SSN ontology in order to make it possible to represent multiple mappings

- Need to offer a methodology

- Need to address other examples and frameworks 